\title{
DOCUMENTS
}

Wayne Westergard-Thorpe

\section{THE PROVISIONAL AGENDA OF THE INTERNATIONAL SYNDICALIST CONGRESS, LONDON 1913}

Opposed to the reformist character, exclusivist structure and socialdemocratic orientation of the Berlin-based International Secretariat of National Trade Union Centres, thirty-seven delegates of revolutionary, direct-actionist labour organizations and propaganda groups from nine European and three Latin American nations assembled at London in September 1913 for the first international syndicalist congress. ${ }^{1}$ The largest pre-war revolutionary-syndicalist organization, the French Confédération Générale du Travail, not only refused to attend the London assembly but actively campaigned against it. The only professedly syndicalist member of the ISNTUC, which it sought to revolutionize from within, the CGT feared the congress might found a revolutionary International to rival the Berlin Secretariat, which would encourage schisms within the labour movement generally and, more directly, threaten the fragile unity of the French organization itself. Its opposition did not prevent French labour bodies, including affiliates of the CGT, from being represented at London, though French submissions are conspicuously absent from the congress agenda.

The London assembly produced the first international declaration of syndicalist principles, which expressed an unequivocal antistatist position. The congress also established an International Syndicalist Information Bureau headquartered at Amsterdam. Most delegates viewed the creation of the Bureau as a temporary measure, as an initial step toward the establishment of a full-fledged International Syndicalist Secretariat to unite revolutionary unions opposed to the reformist Berlin Secretariat. The outbreak of war in 1914, however, put an end to the work of the International Bureau. Though the syndicalists resumed their efforts in the immediate post-war period, not until 1922 did labour bodies opposed

1 For a full discussion of the congress and the controversy surrounding it, see Wayne Westergard-Thorpe, "Towards a Syndicalist International: The 1913 London Congress", in: International Review of Social History, XXIII (1978), pp. 33-78. 
both to the resuscitated International Federation of Trade Unions ${ }^{2}$ and Moscow's highly politicized Red International of Labour Unions, or Profintern, establish an autonomous international organization of revolutionary trade unions, the International Working Men's Association. ${ }^{3}$

No official record of the 1913 London congress ever appeared and the Provisional Agenda is apparently one of the very few documents of the congress to have survived. The document reproduced here is preserved in the papers of Jack Tanner, the British co-president of the congress. ${ }^{4}$ The agenda, compiled from solicited submissions, presumably came from the hand of Guy Bowman, secretary of the British Industrial Syndicalist Education League, under whose aegis the congress met. The League originally intended to convene the assembly in the spring of 1913, but postponed it to the autumn when various foreign organizations objected that the earlier date would allow too little time for preparation. Those favouring postponement insisted upon the necessity of an early circulation of the agenda for amendment and to permit participating organizations to instruct their delegates. But the League neglected congress preparations at London and only quickly assembled the agenda shortly before the congress convened. Thus no "final" agenda appeared. Dispatched to participating organizations only on the eve of the assembly, the hope for advanced discussion of the contents of the Provisional Agenda came to nought. ${ }^{5}$

The agenda indicates the types of issues which a variety of syndicalist organizations considered most pressing and most worthy of discussion at an international congress. It clearly expresses the need for joint action against a capitalism perceived as increasingly internationalized. It also clearly reflects the divergence on tactical and strategical questions between

2 Founded in 1903, by 1913 the ISNTUC grouped affiliates in nineteen countries representing over seven million workers. Its Zürich conference in September 1913 renamed the ISNTUC the International Federation of Trade Unions.

3 See D. A. de Santillan, "La Asociación Internacional de los Trabajaćores", in: La Revista Internacional Anarquista, I (1924-25), pp. 61-64, 86-90, 108-1 1; Arthur Lehning, "Del sindicalismo revolucionario al anarcosindicalismo", in: Cuadernos de Ruedo Ibérico, No 58-60 (1977), pp. 55-75; Wayne Westergard-Thorpe, "Syndicalist Internationalism and Moscow, 1919-1922: The Breach", in: Canadian Journal of History Annales Canadiennes d'Histoire, XIV (1979), pp. 199-234.

4 Jack Tanner Papers, Box 5/2, Nuffield College Library, Oxford. For their complete co-operation I gratefully acknowledge a debt to the staff of Nuffield College Library, and particularly to M. J. Critchlow, Archivist and Assistant Librarian.

${ }_{5}^{5}$ Some syndicalist newspapers such as L'Internazionale (Parma) and Die Einigkeit (Berlin) were able to publish abbreviated versions of the agenda on 27 September, the day the congress opened, and De Arbeid (Amsterdam) as early as 24 September, but in no case did the foreign mandating organizations have an opportunity seriously to consider it before dispatching their delegates. 
the syndicalists and the unions affiliated with the ISNTUC. Issues such as antimilitarism and the general strike, explicitly banned from the conferences of the Berlin Secretariat, ${ }^{6}$ are raised here. All the national syndicalist organizations represented at London were barred from the ISNTUC. They also lacked formal international links among themselves. Advocates of the congress invoked precisely the need to rectify this situation as a chief reason for convening the assembly, and the desire to establish bonds between syndicalist organizations is clearly evidenced by the number of agenda submissions on this question. But about the nature of the bonds to be established there was no unanimity. This question and that of formulating a declaration of syndicalist principles proved the most contentious of those discussed on the floor of the congress.

The Provisional Agenda is reproduced as originally written, without indication or correction of grammatical or other errors. Page numbers have been inserted in brackets. A bracketed asterisk designates those organizations which, though they contributed items to the agenda, were not represented in the congress itself.

INTERNATIONAL SYNDICALIST CONGRESS.

HOLBORN HALL, LONDON.

September 27 to October 2

1913.

PROVISIONAL AGENDA. ${ }^{7}$

1. INTERNATIONAL ASPECT.

2. THEORY AND TACTICS. ${ }^{8}$

3. a) Anti-Militarism.

4. b) Scabbing.

5. c) Emigration.

6. INTERNATIONAL ORGANISATION.

7. INTERNATIONAL NEWSPAPER.

8. INTERNATIONAL LANGUAGE.

9. RELIGIONS AND MORALS OF THE PROLETARIAT.

6 See, for example, Joh. Sassenbach, Fünfundzwanzig Jahre internationale Gewerkschaftsbewegung (Amsterdam, 1926), pp. 17-18 et passim.

7 The unnumbered cover page of the agenda bears the handwritten word "Commission" three times, with various lines indicating that items 2 through 7 were referred to the 


\section{[1] INTERNATIONAL ASPECT}

Reports by the delegates on the position of the Syndicate Movement in their respective countries. ${ }^{9}$

\section{[4] ANTi-militarism ${ }^{10}$}

\section{Germany: Freie Vereinigung deutscher Gewerkschaften}

The revolutionary Syndicalists and war.

\section{Sweden: Sveriges Arbetares Centralorganisation}

That militarism is the greatest obstruction to the emancipation of the working-class and that the building of barracks and warships, the manufacturing of guns, ammunitions and all forms of military equipment, by the workers, for their own destruction is quite incompatible with their interests; and further that this Congress recommend what action should be taken by workers engaged in the manufacture of implements of war.

\section{Holland: (Nederlandsche Federatieve Bond Gemiente Werklieden)}

That the Congress pronounce itself upon the attitude of the revolutionary Trade-Unions in case of war.

resolution committee appointed by the congress. A large $\mathrm{X}$ has been drawn through items 8 and 9 . In the end, the congress formally dealt only with items 1,2 and 6.

8 Two pages, precisely those dealing with "Theory and Tactics", are missing from Tanner's copy of the agenda. Under this rubric the congress, initially centring its deliberations on a submission from the Dutch delegation, drew up a declaration of syndicalist principles. The final draft (quoted in Westergard-Thorpe, "Towards a Syndicalist International", loc. cit., p. 64) shows unmistakable signs of having been largely modelled upon a statement of principles earlier submitted by the National Federation of Building-Trades Workers (Bouwvakarbeiders) of Holland, which also submitted items concerning an international language and newspaper to the agenda. The two missing pages therefore apparently contained the Bouwvakarbeiders' declaration of principles, published prior to the congress in De Arbeid, 3 September 1913, and reproduced in the Appendix.

9 The most complete account of the various national reports is that given in De Arbeid, 4, 8 and 11 October 1913, but see also La Protesta (Buenos Aires), 29 October and 5 November, and Solidaridad Obrera (Barcelona), 16 October.

10 Though antimilitarism was not discussed on the congress floor, Fritz Kater of the Freie Vereinigung deutscher Gewerkschaften, co-president of the congress, observed in his closing remarks that the syndicalists, once sufficiently organized, would make war impossible. Der Pionier (Berlin), 15 October 1913. The issue apparently came up in committee, however, for the Dutch militant Christiaan Cornelissen, a central figure in the congress, later informed Max Nettlau that factionalism had precluded consensus on a resolution against militarism. Nettlau, Unpublished Manuscript, 1895-1914, III B, pp. 604-05, Internationaal Instituut voor Sociale Geschiedenis. Gustav Sjöström, editor of Syndikalisten (Malmö), the newspaper of the Sveriges Arbetares Centralorganisation, later (8 November 1913) declared the failure of the congress to act on the question of antimilitarism to have disappointed the Swedish syndicalists. 
Spain: Associacion Tipografica de La Coruna

What attitude is the universal proletariat to adopt towards wars between nations?

Belgium: Union des Syndicats de la Province de Liege

Anti-militarism or Anti-patriotism?

\section{[5] INTERNATIONAL SCABBING}

Holland: Land[elijke] Fed[eratie] van Metaalbewerkers

That the congress discuss the possibility of preventing International Scabbing. Explanation

As it has often happened that the employers of different countries have supported each other during important conflicts - as for instance when German blacklegs were brought in during the Dutch Dockers and Seamen's strike in 1911 - the National Federation of Metalworkers of Holland is of the opinion that steps should be taken to prevent such Scabbing in future.

\section{Means}

1. By declaring for a Solidarity Strike, as soon as the blacklegs are brought in.

2. By stopping the trains or boats bringing the blacklegs. (The discussion of these points will greatly develop the international solidarity of the working-class as opposed to the internationally organised masters)

3. Discussion of the International General Strike.

\section{Explanation}

We see that the International Class Struggle is showing itself in more violent forms.

Financial support being only a weak weapon that leads to the impoverishment of the strikers and often to the loss of the strike, we, as class-conscious workers are of the opinion that the revolutionary workers should act with greater vigour and grant fullest moral support to the strikers.

As the capitalist tries more and more to enforce national, and the near future international, boycots, the proletariat should make an energetic propaganda in favour of the national and international general strike as such a strike is the most effective weapon in the attainment of international Brotherhood. 


\section{[6] Emigration}

\section{Brazil: Confederacao Operaria Brazileira}

In view of the emigration of the working-class to countries, where, as in Brazil, special laws are in force which deny to foreign workers the right to unite for their emancipation, and place them entirely at the mercy of the Police, who arrest, beat and deport them, what attitude should be adopted by the European Syndicalist Associations ${ }^{11}$

\section{[7] INTERNATIONAL ORGANISATION ${ }^{12}$}

\section{Havana: Union de Dependientes de Cafe}

What methods are the most efficacious, in the opinion of the Congress, to consolidate the organisations of Syndicalist workmen for resistance and revolutionary struggle and how can these organisations be brought daily more closely together until the final object of the workmen is realised?

11 Regarding Brazil, the special law referred to here by the Confederação Operária Brasileira is that of 1907 , which provided the government wide latitude in expelling foreign militants, the mainstay of the labour movement. Anor Butler Macia, Expulsão de Estrangeiros (Rio de Janeiro, 1953), pp. 37-38, reproduces the text of the law. Brazilian elites favoured deportation of foreign activists over domestic imprisonment as "quicker, more efficient, and less liable to be reversed. Moreover, and very important, the government did not have to prove its case to deport; accusations sufficed." Sheldon L. Maram, "The Immigrant and the Brazilian Labor Movement, 1890-1920", in: Essays Concerning the Socioeconomic History of Brazil and Portuguese India, ed. by Dauril Alden and Warren Dean (Gainesville, 1977), p. 195. See also, for a brief account of the deportation legislation as an attack upon the Brazilian labour movement, Edgard Carone, A Republica Velha, I: Instituiçôes e classes sociais, 2nd ed. (São Paulo, 1972), pp. 237-40. By 1913 the situation had grown worse, for in January the government decreed that foreigners resident in Brazil for two years or with Brazilian wives or, if widowed, with Brazilian children, protected from deportation under the original law, were no longer exempt. The Confederação, hoping to counteract Brazilian efforts to attract immigrants, charged some deported militants with publicizing abroad the government's deportation legislation and practices. John W. F. Dulles, Anarchists and Communists in Brazil, 1900-1935 (Austin, 1973), pp. 27-28. It clearly wished to use the London congress for the same purpose. Two Italian delegates at London had personally experienced the antipathy of the Brazilian government towards foreign militants. Edmondo Rossoni had been deported in 1908 for attempting to establish an Escuela Moderna. Victor Alba, Historia del movimiento obrero en América Latina (Mexico City, 1964), p. 101. Prior to the introduction of the 1907 law, Alceste De Ambris had fled Brazil to avoid a prison sentence. Renzo De Felice, Sindacalismo rivoluzionario e Fiumanesimo nel carteggio De Ambris - D'Annunzio (1919-1922) (Brescia, 1966), p. 13

12 The type of organization to be established elicited a lengthy and lively debate. L'Action Ouvrière (Liège), I September 1913, had rightly anticipated that a crucial issue would be whether to form an International or simply a Correspondence Bureau. While one group of delegates, forcefully represented by De Ambris of Italy, proposed that only an International Syndicalist Information Bureau be established, the German and Dutch delegates urged the formation of a full-fledged Syndicalist International. The possibility 
Sweden: Sveriges Arbetares Centralorganisation

That, in view of the increasing international organisation of Capital and Capitalists, an active and powerful International Syndicalist Organisation is necessary to enable the working-class to fight organised Capital on international lines.

\section{Italy: Unione Sindacale Italiana}

Definition of a permanent relationship between the Syndicalist Organisations of the various countries.

\section{Spain: Accion y Cultura, Badajoz [*]}

That, in view of the necessity for world-wide solidarity and prompt and decisive action on the part of revolutionaries, all Syndicalist and Anarchist groups should come together to found a "New Red International" with a secretariat for registering statistics of all the revolutionary forces.

\section{Spain: Grupo Sindicalista, Gijon [*]}

a) That the Congress decides to unify the Syndicalist movement by the creation of national federations which, as far as Spain is concerned, would crystalise the trade organisations, and render the Regional Confederation of Catalonia national. ${ }^{13}$

[8] b) The Congress also recommends the constitution of Syndicalist Groups in all towns of any industrial importance, and that these in their turn constitute national federations completely independent of other federal trade organisations.

c) That the Confederations hold their Congress at a moment they think most opportune so as to follow, in its most minute details, the progress of Syndicalist organisation and eliminate such defects as will have been observed.

of schism within the French CGT following the establishment of a second tradeunion International played an important role in the debate. The Dutch-German group eventually yielded, though with the understanding that a second congress to be held in 1914 or 1915 (and prevented by the war) would return to the issue. They nevertheless succeeded in securing Amsterdam as the seat of the International Bureau against De Ambris's proposal of Paris. On the debate, see Westergard-Thorpe, "Towards a Syndicalist International", pp. 65-70. A number of delegates, believing the distinction between a Bureau and an International to be no more than a tactical ploy, took the formation of the Bureau to constitute the birth of "the new Red International". Syndikalisten, 18 October 1913; see also Les Temps Nouveaux (Paris), 18 October.

13 The decision to establish a national syndicalist organization in Spain had already been taken in 1910, though the Confederación Nacional del Trabajo had been banned a year later. A pioneer organizer of the national Confederación, José Negre, represented the Catalonian organization at the congress. The Confederacion Nacional emerged from clandestinity in 1914. 
d) That the national federations of Groups hold their annual or bi-annual congress in which they will study questions of a doctrinal character, which, owing to their importance, cannot be solved by the Groups.

e) That International Congress be held periodically with a view to strengthen the bonds of union between the exploited of the whole world, and act in common accord in regarding to the common interest of the organisations.

f) That the resolutions put forward by each delegate, and the final resolution which will accrue from them be published in all languages represented at the Congress, so that they might serve as guide to the class action of the organisations which go ahead with the principles of Revolutionary Syndicalism. The cost of these publications to be comprised in the expenses of the Congress to be Pooled by the organisations represented.

Germany: Freie Vereinigung deutscher Gewerkschaften

Foundation of an "INTERNATIONAL"

\section{Holland: Land[elijke] Fed[eratie] van Textielarbeiders}

That this Congress decides to collect statistics of importance relative to the wages, the working-conditions etc, of the textile trade of each country.

Explanation

It has happened that textile Workers, striking for an [9] improvement in their conditions, have been defeated by the employers producing information concerning the wages, working-hours, etc. in other countries, which particulars the the strikers, having no facts of the kind at their disposal, have been unable to controvert.

Thus it would be great impotance to the textile workers of each country to know under what conditions operatives of the others countries are working.

Spain: Association Tipografica de La Coruna

What means are best, and most likely, to show tangible results for neutralising the perturbing effects created by machinery in all Trades?

\section{[10] INTERNATIONAL NEWSPAPER}

Spain: Accion y Cultura [*]

That a paper, with branch offices for translation in all countries, be started, and that such paper be the organ of the "New Red International".

Sweden: Sveriges Arbetares-Centralorganisation

That, as the "Bulletin International" has heretofore, in the absence of any international, revolutionary organisation, been edited by private initiative 
and devotion, we propose that in the event of an International Syndicalist Organisation being established which we hope the editorship of this paper should become the concern of the newly formed Syndicalist International.

\section{Holland: Land[elijke] Fed[eratie] van Bouwvakarbeiders}

That this Congress discuss in private session the management of the "International Bulletin". ${ }^{14}$

\section{[11] INTERNATIONAL LANGUAGE}

\section{Holland: Land[elijke] Fed[eratie] van Bouwvakarbeiders}

This Congress, recognising that the working-class should no longer remain split into sections owing to the differences in their languages, is of the opinion that the working-class must themselves remedy this by employing one language in order to render easier the duties of delegates and correspondents; and therefore proposes that the workers of each country should study "Esperanto" in order that it may be used at future congresses, and become eventually the language of the working-class.

\section{Sweden: Sveriges Arbetares Centralorganisation}

That, in view of the undue advantages enjoyed by delegates speaking in their own tongues, future International Congresses be conducted in an International Language decided upon by this Congress; further that, in view of the international organisation of capital, an International Language will be of great assistance towards working class unity; and further, that, seeing that "Esperanto" and "Ido" are two rival International Languages,

14 The reference here and in the preceding Swedish entry is to the Bulletin International du Mouvement Syndicaliste, edited by Christiaan Cornelissen, which had emerged following the 1907 Amsterdam Anarchist Congress, in which the merits of syndicalism had been debated. As major financial backers, the Dutch and Swedish syndicalists were justified in making these proposals about a privately managed periodical. Originally funded by the French, German, Dutch and Bohemian movements, in the period preceding the congress the Nationaal Arbeids Secretariaat of Holland, the Arbetares Centralorganisation of Sweden, the Freie Vereinigung deutscher Gewerkschaften of Germany, and the French CGT financed Cornelissen's Bulletin, which also received occasional contributions from the American Industrial Workers of the World. Cornelissen, "Strijd, lief en leed in de Oude Socialistische Beweging en de Vakorganisaties: Persoonlijke herinneringen", p. 441, Internationaal Instituut voor Sociale Geschiedenis. The day after the congress closed the Dutch and German delegates met with Cornelissen to discuss the previous financing of the Bulletin, Die Einigkeit (Berlin), 11 October 1913. Cornelissen later terminated his own Bulletin when the International Syndicalist Information Bureau at Amsterdam appointed by the congress began publishing a Bulletin with the same title (first issue: 1-5 April 1914). Cornelissen edited the Bureau's Bulletin, "Strijd, lief en leed", p. 439. 
This Congress, after deciding: (a) which language is best known to the working-class? (b) which language, irrespective of its popularity, has the most linguistic advantages?

Shall select one language for international use of the working-class. ${ }^{15}$

\section{[12] RELIGION AND MORALS}

\section{Poland: Polska Groupa Syndykalisci Revolucyjne, Krakow ${ }^{16}\left[{ }^{*}\right]$}

The idea of the international revolutionary Syndicalist movement corresponds to the natural evolution of humanity.

The whole of the human race consists of two sharply divided and opposed factions: on the one hand, the mass international in its character, of the exploited and oppressed, i.e. the Proletariat, the wage-earners, the poor peasants, poor tradesmen and all the unhappy and downtrodden of the 5th estate, and also all common soldiers; opposed to these stand the possessors of power and capital, the privileged and exploiting.

The whole mass of the oppressed moves forward on the lines of evolution and organises itself syndicalistically in a natural manner. It is, so to say, a biologically inevitable organisation.

The movement must progress quickly, vigorously, even stormily, yet it must be exact, as are all great natural phenomena in the animal world. The movement must develop itself indirect, ${ }^{17}$ revolutionary action. This Syndicalistic wave will of course, break into two currents, one allowed by the State, one illegal: - the Syndicalist one. But it must be whole hearted, that is it must lead straight to the point. It is a natural elementary force that can

15 Guy Bowman voiced his opinion concerning the relative linguistic merits of the two languages in a pre-congress interview: "Some of the delegates propose that Esperanto should be adopted, and some Ido. I am not much in love with Ido because one cannot swear in that language." Pall Mall Gazette, 27 September 1913. Lack of time prevented discussion of an international language either on the floor of the assembly or in committee. Despite the apparent neutrality of its submission, the Swedish organization strongly favoured Ido, and Syndikalisten, 8 November, much lamented the failure of the congress to take up this point of the agenda.

16 A "proof copy" of the delegates' list (Tanner Papers) indicates that the congress organizers anticipated that A. Wroblewski would represent the Polish Revolutionary Trade Union Group, though he did not appear. Shortly before the congress convened, Les Temps Nouveaux, 20 September, apprised its Polish readers that Dr Augustin Wroblewski had recently been "interné comme fou", and warned them against him as "un homme qui a cessé d'être responsable de ses actes". It specifically urged them to disregard the flyers circulated by Wroblewski characterizing a number of the most reliable and active members of the Polish movement as police spies and agents provocateurs.

17 Read "in direct". 
be stopped as little as a flood or a prairie fire; or rather in its functioning, it is organised as the origin and migration of a shoal of fish.

The human race to-day, is organising itself as one great, mutually dependant family, and our movement indicates the principal expression of this work of organisation.

The people, becoming fraternal, renew themselves in spirit and together aspire towards the swift development [13] of material conditions. For this rising multitude, which numbers one and a half millions, Science and that knowledge which is intuitive are, practically, the same thing. Also should their judgments upon human deeds and the value of life be common to all, and form the Revolutionary morals of humanity.

Every deed that leads to the development of ourselves and humanity is good. Every deed that militates against the development of ourselves and humanity is bad.

These, our morals, are higher than the Christian's morals, since, for us, to exploit another or to renounce our own development is a crime.

A common world-outlook forms itself based upon knowledge, a general pressing forwards. This striving for true brotherhood and true liberty tends instinctively towards a great creative development of all human beings, and towards the natural organisation of humanity into a communistic family.

The social enthusiasm, the clear seeing revolutionary impetus of the human mind and heart, the great ambitions of the human - will, which gather themselves together for Revolutionary achievment - those are all expressions of the new religion of the proletariat, which leads to the happiness of man on earth, and thus distinguishes itself from the Christian Religion; it also supersedes the latter by virtue of its higher faith in the possibility of human happiness.

This Revolutionary Religion, these Revolutionary morals should be cultivated in the Syndicalist movement, and should become the greatest factor in its building up.

\section{APPENDIX}

The declaration of principles submitted to the agenda by the Dutch Landelijke Federatie van Bouwvakarbeiders, from De Arbeid, 3 September 1913

[E]rkennende dat de arbeidende klasse van alle landen gebukt gaat onder de kapitalistische overheersching op politiek en economisch terrein, plaatst zich zonder eenig voorbehoud op het standpunt van den klassenstrijd en wil zijn de internationale zelfstandige onafhankelijke, op vrijwillige samenwerking berustende, klasseorganisatie van de arbeiders; 
zij stelt zich tot taak het behartigen van de oogenblikkelijke en toekomstige belangen, door bestrijding van de internationale kapitalistische productiewijze op politiek en economisch terrein;

verklaart, dat de klassenstrijd een noodwendig gevolg is van 't privaateigendom van grond en arbeidsmiddelen, vandaar acht de internationale zelfstandige onafhankelijke vakorganisatie haar doel gelegen in de socialiseering daarvan en meent zij, dat de vakorganisatie in de verschillende landen zich in de toekomst zullen ontwikkelen tot productieve voortbrengingsgroepen, die de voortbrenging en verdeeling van den maatschappelijken rijkdom hebben te regelen;

erkennende eindelijk, dat de internationale zelfstandige onafhankelijke vakorganisatie zich dan eerst met succes kan wijden aan haar taak, wanneer politieke en godsdienstige meeningsverschillen geen invloed meer hebben op hare strijdmiddelen;

verklaart zij, dat haar strijd is een economische, daarmede bedoelende, dat zij haar doel niet tracht te bereiken door het geven van opdrachten aan regeeringslichamen noch leden daarvan, maar door rechtstreekschen druk door de arbeiders zelven, berustende op de kracht der organisatie.

Op grond van bovenstaande erkenningen en verklaringen, roept het Internationaal Revolutionair Vakvereenigings-Congres de arbeiders van alle landen op, zich te organiseeren in zelfstandige onafhankelijke industrieele vakfederaties in eigen land en zich eens te gevoelen met de arbeiders van alle landen, opdat hierdoor op internationaal gebied de klasse van den arbeid zich machtig organiseert tot vrijmaking van de kapitalistische overheersching op politiek en economisch terrein. 